\title{
CpG ODN 1826 Enhances the Efficacy of Idiotype DNA Vaccine Administered Intrasplenically
}

\author{
Hongtao $\mathrm{Li}^{1,2}$ and Swapan K. Ghosh ${ }^{1, *}$ \\ ${ }^{1}$ Department of Biology, Indiana State University, Terre Haute, IN 47809, USA \\ ${ }^{2}$ Department of Microbiology and Immunology, Indiana University School of Medicine, Terre Haute, IN 47809, USA
}

\begin{abstract}
Effectiveness of intrasplenic administration of plasmid vaccines has been of interest in vaccine research, because the spleen is strategically located to filter antigens in circulation and provides the milieu to mount vigorous immune responses against trapped antigens. Intrasplenic vaccination with the naked plasmid DNA and a Cytosine Phosphorothiolated Guanine ( $\mathrm{CpG}$ ) adjuvant is expected to engender lasting effects. Specific unmethylated CpGcontaining Oligodeoxynucleotides ( $\mathrm{CpG} \mathrm{ODN})$ can serve as a danger signal to the vertebrate immune system. This study was initiated to evaluate a single chain variable fragment $(\mathrm{scFv})$ construct (Id-Th) which encodes the Id of a murine lymphoma 2C3-associated immunoglobulin (Ig) and a $\mathrm{T}$ helper epitope. Our previous studies show that scFv plasmid expressing $2 \mathrm{C} 3$ idiotype are processed and recognized by Id-specific cytotoxic T-lymphocytes in vitro, but in vivo they evoke only moderate responses when administered by intramuscular or intradermal routes. In this report, we addressed the effectiveness of Id-Th, a new 2C3 Id DNA vaccine, delivered intrasplenically. We show here that, after intra-splenic immunization of Id-Th, the appearance of Id-antigen in sera of tumor-challenged mice is significantly delayed (52.4\% decrease), $36.8 \%$ of mice survive a challenge of $1 \times 10^{3}$ live 2C 3 tumor cells. Furthermore, inclusion of CpG ODN 1826 as adjuvant further improves vaccine efficiency and delays the appearance of Id-antigen (64.9\% decrease), and enhances the survival rate by $53.8 \%$. In summary, intrasplenic delivery of DNA vaccines with CpG adjuvant is a potentially useful immunotherapeutic modality and the mechanism remains to be investigated.
\end{abstract}

Keywords: Idiotype vaccine, $\mathrm{scFv}$, DNA vaccine, $\mathrm{CpG}$ adjuvant, intrasplenic delivery, murine lymphoma.

\section{INTRODUCTION}

Plasmid-based DNA vaccines expressing specific disease-related antigens appear promising in a wide variety of experimental models for infectious diseases, cancer, and autoimmunity [1]. Clinical trials in humans, however, have been disappointing; this highlights the need to optimize efficacy of a DNA vaccine. The effectiveness of any vaccine depends not only on the antigen but also on many other factors, including the route of administration and appropriate adjuvants.

The spleen and lymph nodes are the most highly organized secondary lymphoid organs with distinct areas for T-cell and B-cell activities. The spleen is more likely to respond rapidly than lymph nodes to systemic infections; it filters and traps blood-borne antigens, while lymph nodes are specialized for tissue-associated antigens. Experiments with radioactively labeled lymphocytes show that more recirculating lymphocytes pass daily through the spleen than through all the lymph nodes combined [2]. Intra-splenic immunization has been a subject of investigations in many studies [3]. Kundig group reported that fibroblast-induced $\mathrm{T}$ cells respond only when they reach the spleen [3a]. Fibroblasts are found to be very potent antigen presenting cells (APCs) if injected directly into the spleen; they can efficiently induce

*Address correspondence to this author at the Department of Biology, Indiana State University, Terre Haute, IN 47809, USA;

Tel: 812-237-2416, Fax: 812-237-4480;

E-mail: swapan.ghosh@indstate.edu, hli2@iupui.edu cytotoxic T lymphocytes (CTLs) in the cytokine-rich lymphoid environment. Subsequently, Velikovsky et al. have shown that plasmid DNA encoding p18 protein from Brucella abortus, delivered by intra-splenic immunization, expressed in the spleen for at least 20 days after one immunization [3b]. Maloy et al. showed that immunization with a naked DNA by direct injection into the spleen enhanced its immunogenicity by about 100 fold, inducing a strong specific CD8+ CTL response against lymphocyte choriomenigitis virus glycoprotein (LCMV-G) gp33 [3c]. White et al. demonstrated that administration of a low dose of pCEA plasmid by the intra-splenic route produced a stronger antibody response to carcinoembryonic antigen (CEA); this model of administration provides better protection against the tumor challenge than intramuscular administration of a low dose pCEA [3d]. A single intra-splenic injection of DNA encoding Ig VH gene in mice was also reported to be effective in inducing specific and protective immune responses [3e, f]. Although it does not always ensure a systemic immune response $[3 \mathrm{~g}]$, intrasplenic delivery could induce specific CD4+ and CD8+ T cells [3h].

Adjuvants are known to enhance the immunogenicity of the antigen if administered simultaneously with that antigen. Besides the traditional adjuvants, for instance, alum and Freund's adjuvants, unmethylated Cytosine Phosphorothioated Guanine-containing Oligodeoxynucleotides (CpG ODN) can help stimulate and prolong immune responses. CpGs act as danger signals in much the same way that bacterium or virus DNA does and are recognized by the toll like receptor- 9 
(TLR-9) in antigen presenting cells (APC) in mice, including $\mathrm{B}$ cells, dentritic cells, and macrophages, which respond to CpG through secreted cytokines, especially proinflammatory interleukin (IL)-6, and Th1 promoting IL-12 [4]. In combination with Fms-like tyrosine kinase 3 (Flt3)-ligand (FL), TLR-9 CpG DNA can enhance cellular immunity against HIV virus as shown by Kwissa et al. [5]. Grossmann et al. reported that synergistic TLR ligand $\mathrm{CpG}$ and Poly I:C can improve the CD8+ $\mathrm{T}$ cell responses in priming efficacy of DNA vaccines encoding dendritic cell targeted antigens [6]. However, not all unmethylated $\mathrm{CpG}$ are stimulatory. A specific 20-mer CpG ODN 1826 synthesized with a nucleaseresistant Phosphorothioated backbone appears to be an ideal immunostimulatory adjuvant [7]. Providing this $\mathrm{CpG}$ along with DNA or peptide vaccines should activate Th- 1 function and enhance protective anti-tumor or anti-pathogen immune responses.

In this study, we demonstrated that a membrane-form of a tumor associated antigen (TAA) idiotype-based plasmid Id-Th (with or without a CpG adjuvant) lowers serum antigen in the tumor bearing mice. However, the intra-splenic administration of Id-Th alone is only marginally protective against the tumor challenge. The inclusion of Th1 immune response promoting adjuvant CpG ODN 1826 in the Id-Th vaccine significantly improves the survival rate.

\section{MATERIALS AND METHODS}

\section{Mice}

Seven to 11 week old, female and male BALB/c mice were obtained from Harlan-Spragne-Dawley, Inc. (Indianapolis, IN), bred and maintained at the Indiana State University animal facility according to the principles of laboratory animal care followed under the guidance of the Indiana State University Animal Care and Use Committee.

\section{Tumor Cells}

The tumor cell used here was a murine lymphoblastoma 2C3, which has been studied extensively in this lab. This tumor expresses both membrane and secreted forms of Ig $(\gamma 1, \kappa)$, whose natural ligand was phthalate. Thus, binding of sera from TBA on phthalate-coated ELISA plate (described below) has been a convenient way to monitor tumor take, and tumor progression or regression.

The P815 mastocytoma neither expresses nor secretes Ig and was used as a control in tumor-specificity studies. The P815A7 antigen presenting transfectoma cell line was derived from a mastocytoma, P815; using the calcium phosphate precipitation transformation method [8], the stable P815A7 transfectant has been established under zeocin and G418 selection in vitro.

\section{Reagents}

Salt-free 20-mers of CpG ODN 1826, obtained from QIAGEN, California, have the following sequence: $* \mathrm{C} * \mathrm{C} * \mathrm{~A} * \mathrm{~T} * \mathbf{G} * \mathbf{A} * \mathbf{C} * \mathbf{G} * \mathbf{T} * \mathbf{T} * \mathrm{C} * \mathrm{C} * \mathrm{~T} * \mathbf{G} * \mathbf{A} * \mathbf{C} * \mathbf{G} * \mathbf{T} * \mathbf{T} \quad(*$ stands for phosophorothioation bond) [7a-d]. The plasmid vaccine used was the membrane form of VHVL, termed IdTh (7156 bp); it was constructed using a pDisplay vector, from Invitrogen, California. The initial cloning of $\mathrm{VH}$ and VL from the genomic DNA of 2C3 is described elsewhere [8]. At the ApaI and PstI in the multiple cloning sites, the VHVL-gfpz fusion gene was cloned first, and a linker of 72 bp (including the Th epitope which has been highlighted in the 5'spacer as below) has been inserted between the $\mathrm{VH}$ and VL genes, as shown in Fig. (1). Restriction enzyme digestion and sequence analyses confirmed the identity of these constructs. The sequence of the $72 \mathrm{bp}$ Th epitope (from Tetanus toxin Fig. 1) was used as follow; Th has been reported to be a Th lymphocyte activating epitope in earlier studies [9].

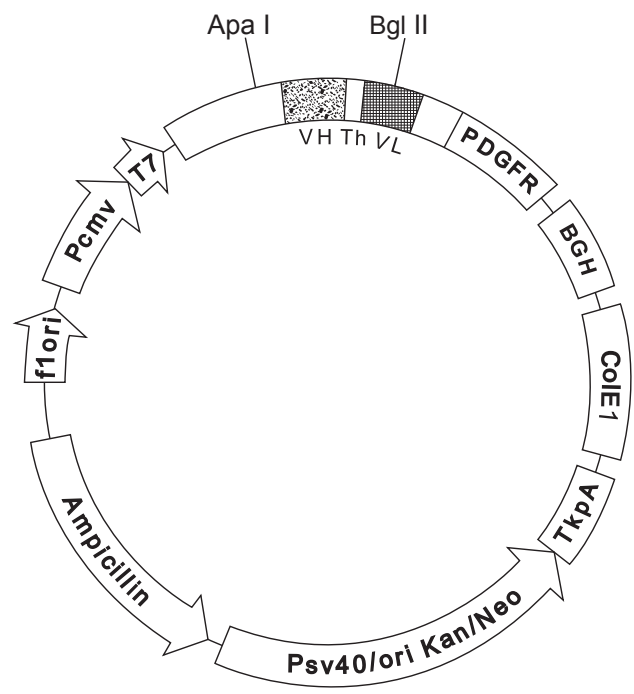

Fig. (1). Schematic representation of plasmid DNA Id-Th constructed for use as a vaccine. The Id-Th construct expresses a membrane form of $\mathrm{scFv}$ with tt830-844 tetanus toxin Th epitope imbedded within $\mathrm{scFv}$ consists of VH and VL (Laxmanan et al., 2001). $\mathrm{VH}$ is the murine $2 \mathrm{C} 3 \mathrm{~B}$ cell lymphoma $\gamma$ heavy chain $\mathrm{V}$ region, and $\mathrm{VL}$ is the $\kappa$ light chain $\mathrm{V}$ region.

5' spacer

GCTGGCGGTGGCCAGTACATCAAGGCCAACTCCAAATTTATAGGCATTACCGAGCTGGGTGGCGGCGGTGCA

3'spacer

CCGCCGCCACCCAGCTCGGTAATGCCTATAAATTTGGAGTTGGCCTTGATGTACTGGCCACCGCCAGCTGCA

All the plasmids DNA were bulk prepared and made endotoxin-free (< $100 \mathrm{EU} / \mathrm{mg}$ ) at Aldevron Company (Fargo, North Dakota, USA).

\section{Immunization Protocol}

The procedure was adopted from Cano et al. with minor changes [3f]. Anesthetized mice were shaved, and then a small (3 to $4 \mathrm{~mm}$ ) incision was made with scissors in the abdomen. The spleen was then exposed through this incision, and DNA was injected using a 27-gauge needle. Afterward, the abdomen was immediately sutured using 4-0 sterile nonabsorbable surgical threads. 


\section{RNA Isolation and RT-PCR}

RT-PCR was performed on the transfectants and homogenized spleen tissues to verify transgene expression at the mRNA level. RNA was then isolated from the $5 \times 10^{6}$ target cells using a total RNA isolation kit (Promega, Wisconsin). After total RNA extraction and first strand cDNA synthesis using random hexamer primers (Promega, Wisconsin), appropriate VH and VL specific primers were used to amplify and detect their mRNA expression.

\section{ELISA}

Prophylactic intrasplenic immunizations of the BALB/c mice with plasmid Id-Th with or without CpGs were performed in the experimental group, while the control group was inoculated with empty vector pDisplay. After 2 to 3 weeks of inoculation, the mice were challenged with $1 \times 10^{3}$ $2 \mathrm{C} 3$ tumor cells. Twenty four days after tumor challenge, the mice were bled and 2C3 Id and Ig antigen (the nominal $\mathrm{Ag}$ ) levels in sera were determined as described previously [8, 10]. Briefly, different dilutions of test sera from control and immune mice were added to 96-well ELISA plates coated with phthalate-BSA conjugate $(10 \mu \mathrm{g} / \mathrm{ml})$ that have been thoroughly blocked with $1 \%$ bovine serum albumin. After incubation for 1 hour at $37^{\circ} \mathrm{C}$, purified rabbit-anti-mouse Ig HRP antibody was added to the wells and incubated for an additional 45 minutes at $37^{\circ} \mathrm{C}$. Subsequently, the plates were washed, and then color developed with o-phenylenediamine (OPD), and read at $490 \mathrm{~nm}$.

\section{Statistics}

The serum tumor antigen level data were analyzed for variance by single factor ANOVA and Student's $t$ test.

\section{RESULTS}

\section{Plasmid DNA Expression In Vitro and In Vivo}

We first evaluated the expression of our construct in vitro by transfecting an antigen presenting mastocytoma cell line, P815, and generating a stable transfectant, P815A7. The mRNA expression of scFv in this transfectoma cell line was tested by RT-PCR. The results in Fig. (2a) revealed the expression of a full-length modified $\mathrm{scFv}(786 \mathrm{bp})$ that included not only VH (363 bp) and VL (351 bp) together, but also the Th epitope linker insert (72 bp). No similar 786bp band was evident in the $2 \mathrm{C} 3$ cell line, which showed only VH and VL separately, as expected (Fig. 2a). The plasmid expression in spleen experiment was also done 3 days after administration of the vaccine, and the results were shown in Fig. (2b).

\section{CpG Contents of Naked DNA and the Rationale for Additional CpG ODN 1826}

In many studies, adjuvants such as $\mathrm{CpG}$ have been shown to augment efficacy of plasmid DNA vaccines. The plasmid backbone used in the immunization itself contains a certain amount of $\mathrm{CpG}$ motifs, together with synthetic oligodeoxynucleotides (ODN) that contain cytosinephosphorothiolated guanine motifs as additional adjuvants that has been known to stimulate the host immune system in a similar way. To determine whether this is also applicable to plasmid Id-Th vaccines, we first analyzed $\mathrm{CpG}$ contents in
DNA vaccine construct. Our statistical analysis on relative contents of the four most stimulatory and four most unfavorable or non-stimulatory CpGs [11] in both strands of Id-Th plasmid are given in Table 1a. In particular, the amount of stimulatory sequence GACGTT in $40 \mu \mathrm{g}$ of Id-Th was about $2.04 \times 10^{13}$ (based on the MW of plasmid 660 $\mathrm{g} / \mathrm{mole} / \mathrm{bp}$ ). And in the empty vector, it is about the same $\left(2.05 \times 10^{13}\right.$, the injected amount) (Table $\left.1 \mathbf{b}\right)$. The addition of $50 \mu \mathrm{g}$ of adjuvant CpG ODN 1826 to Id-Th plasmid raised the stimulatory $\mathrm{CpG}$ to $4.75 \times 10^{15}$. This was about a 233 times increase in the quantity of the stimulatory hexamer GACGTT.

a
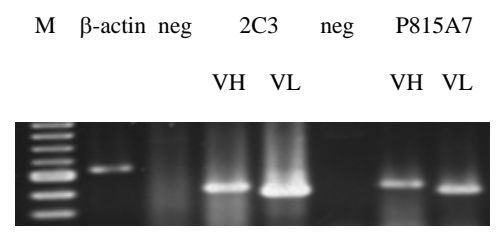

P815A7 -RT Marker P815 2C3 -RT $\beta$-actin

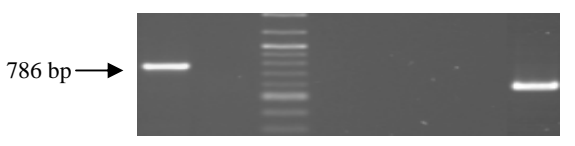

b

P815A7 P815 Spleen -RT M $\beta$-actin

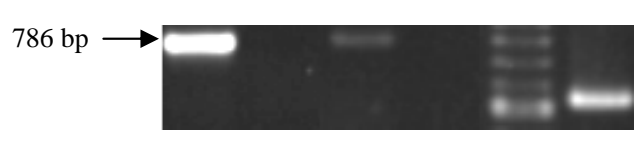

Fig. (2). (a). Demonstration of scFv mRNA in transformed P815A7 cells and $2 \mathrm{C} 3$ tumor line. (b). Expression of $\mathrm{scFv}$ construct in vitro (P815A7) and in vivo (spleen 3 days after immunization).

\section{Monitoring of Serum Tumor Antigen Level as a Measure of Vaccine Efficacy}

We assessed whether progression/regression of the tumor in vivo correlated with the serum level of the tumor associated antigen (TAA). Clinically, serum antigen level has been shown to be a good indicator of the efficacy of the therapeutic treatments. The TAA, in this case, 2C3-Ig level in tumorchallenged mice 2-3 weeks after prophylactic intrasplenic vaccination reflected a correlation between the serum antigen level and tumor prognosis. Fig. (3) shows that the serum 2C3-Ig level 24 days after the tumor challenge was $22.11+/-$ $8.187 \mu \mathrm{g} / \mathrm{ml}$ in the vaccine group, and $16.29+/-8.048 \mu \mathrm{g} / \mathrm{ml}$ in the vaccine plus $\mathrm{CpG}$ group, whereas, in the empty vector group it was $46.46+/-0.7259 \mu \mathrm{g} / \mathrm{ml}$. Thus, there was significant decrease $(\mathrm{p}=0.022)$ in tumor progression in mice treated with Id-Th with or without $\mathrm{CpG}(64.9 \%$ and $52.4 \%)$ compared to the empty vector group.

\section{Effects of Id-Th DNA Vaccine with and without CpG on Mouse Survival Rate}

In order to evaluate the in vivo efficacy of the Id-Th and the adjuvant efficacy of CpG ODN 1826, groups of mice 
Table 1a. Analysis of Id-Th Constructs for the Presence or Absence of Stimulatory and Non-stimulatory Bacterial CpG Sequences

\begin{tabular}{|c|c|c|c|}
\hline \multicolumn{2}{|c|}{$\begin{array}{c}\text { The Four Most Stimulatory or Non-Stimulatory } \\
\text { CpG-Containing Sequences }\end{array}$} & $\begin{array}{c}\text { Numbers in Id-Th Positive } \\
\text { Strand (7156bp) }\end{array}$ & $\begin{array}{c}\text { Numbers in Id-Th Reverse } \\
\text { Complement Strand (7156bp) }\end{array}$ \\
\hline \hline \multirow{3}{*}{$\begin{array}{c}\text { Stimulatory } \\
\text { CpG hexamers }\end{array}$} & GACGTC & 5 & $\mathbf{3}$ \\
\cline { 2 - 4 } & GACGTT & 1 & 3 \\
\cline { 2 - 4 } & AACGTC & 2 & 2 \\
\hline \multirow{3}{*}{$\begin{array}{c}\text { Non-stimulatory } \\
\text { CpG hexamers }\end{array}$} & AACGTT & 2 & 2 \\
\cline { 2 - 4 } & TCCGGA & 3 & 1 \\
\cline { 2 - 4 } & TCCGGG & 1 & 3 \\
\hline
\end{tabular}

Table 1b. Analysis of Empty Vector (E.V.) for the Presence or Absence of Stimulatory and Non-stimulatory Bacterial CpG Sequences

\begin{tabular}{|c|c|c|c|}
\hline \multicolumn{2}{|c|}{$\begin{array}{c}\text { The Four Most Stimulatory or Non-Stimulatory } \\
\text { CpG-Containing Sequences }\end{array}$} & $\begin{array}{c}\text { Numbers in E.V. Positive } \\
\text { Strand (5325bp) }\end{array}$ & $\begin{array}{c}\text { Numbers in E.V. Reverse } \\
\text { Complement Strand (5325bp) }\end{array}$ \\
\hline \hline \multirow{3}{*}{$\begin{array}{c}\text { Stimulatory } \\
\text { CpG hexamers }\end{array}$} & GACGTC & 4 & 3 \\
\cline { 2 - 4 } & GACGTT & 1 & 2 \\
\cline { 2 - 4 } & AACGTC & 1 & 2 \\
\hline \multirow{3}{*}{$\begin{array}{c}\text { Non-stimulatory } \\
\text { CpG hexamers }\end{array}$} & AACGTT & 0 & 0 \\
\cline { 2 - 4 } & TCCGGA & 0 & 1 \\
\cline { 2 - 4 } & TCCGGG & 0 & 0 \\
\hline
\end{tabular}

2C3Ig among Id-Th, Id-Th plus CpG and empty vector

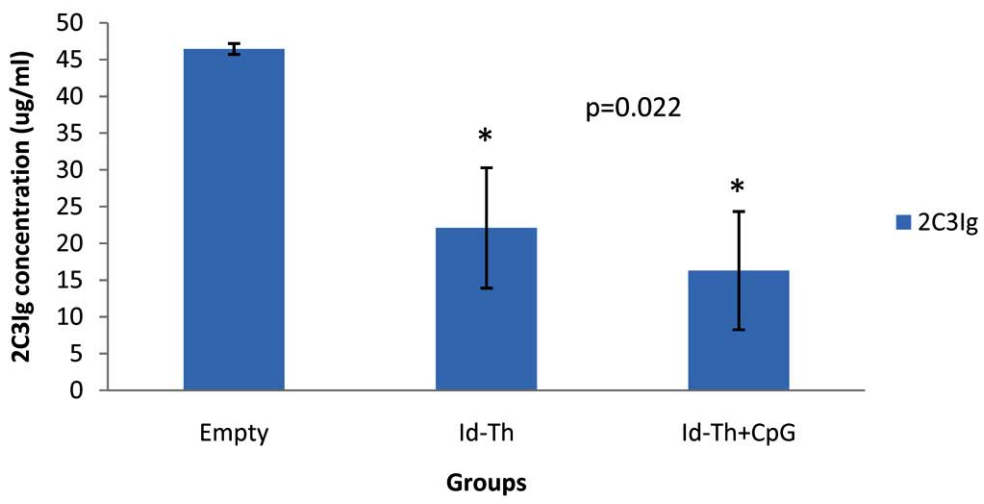

Fig. (3). The serum TAA level (2C3Ig concentration) in mice 24 days after a challenge with live $2 \mathrm{C} 3$ tumor cells $\left(1 \times 10^{3}\right)$; empty vector $(\mathrm{n}=7)$, vaccine Id-Th $(\mathrm{n}=8)$ and Id-Th plus $\mathrm{CpG}$ group $(\mathrm{n}=10)$. This is a pooled result from at least two times experiments with $3-5$ animals in each group. $\left(\mathrm{F}_{2,22}=4.564, \mathrm{P}=0.022\right)$.

were intrasplenically injected with the vaccine in the presence or absence of CpG ODN1826. The results in Fig. (4) show that the Id-Th vaccine groups compared to the emptyvector control group were only marginally improved $(36.8 \%$ or $7 / 19$ verse $30 \%$ or $3 / 10$ ). However, the application of the
CpG ODN 1826 along with the Id-Th significantly improved the survival rate to about $53.8 \%$ (7/13). Thus, a single intrasplenic administration of Id-Th not only reduced the serum level of TAA, as shown above, but it also has improved survival rate, particularly when $\mathrm{CpG}$ was included. 


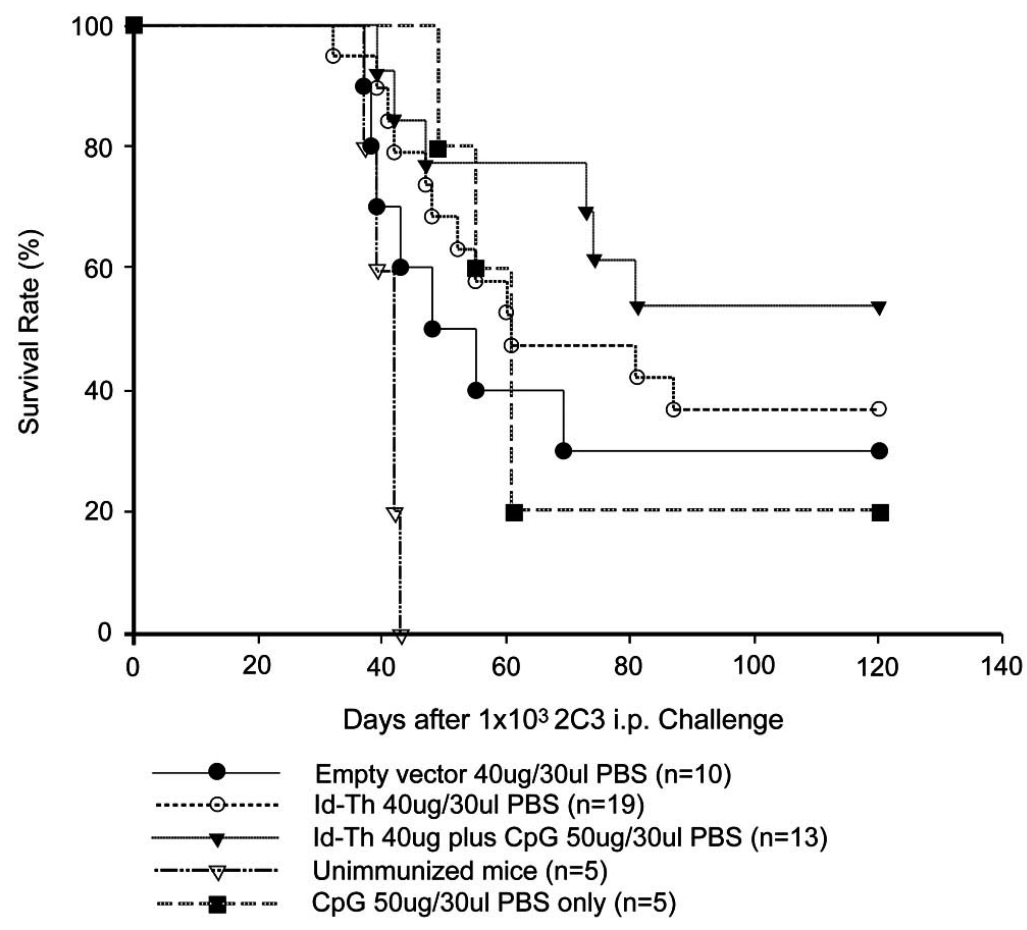

Fig. (4). Relative efficacy of Id-Th plasmid vaccine with or without CpG. The survival of mice was recorded following intrasplenic administration of control or experimental plasmid DNAs, and subsequent challenge with $1 \times 10^{3}$ tumor cells.

\section{DISCUSSION}

The overall goal of this study was two-fold: (1) design a $\mathrm{scFv}$ plasmid with a built-in adjuvant, a non-self tetanus toxoid-derived Th epitope, as a linker to the construct, and (2) assess this Id-Th's immunogenicity following intrasplenic administration in the presence or absence of an additional immunostimulatory molecule, $\mathrm{CpG}$ adjuvant. While CpG is widely used in DNA vaccine strategy [4b], incorporation of Th epitope in vaccine construct has been rather limited [9b]. The regional difference in host microenvironment is often a factor in the consideration of efficacy of an immunization protocol. Our previous studies have shown that $\mathrm{scFv}$ plasmid expressing $2 \mathrm{C} 3$ idiotype are processed and recognized by Id-specific cytotoxic T-lymphocytes in vitro, but in vivo they evoke only moderate responses when administered by intramuscular or intra-dermal routes [12]. Intrasplenic vaccination is an attractive route of immunization, as it provides ready exposure of tumor antigen to blood cells of innate and acquired immunity in circulation. The advantage of a DNA vaccine is that, after transfection in the splenic environment, it could provide a sustained supply and release of the appropriately processed antigen.

In this study, the transfection efficiency is clearly evident in expression both in vitro and in vivo of a naked Th epitope encoding $\mathrm{scFv}$ plasmid. The existence of a $786 \mathrm{bp}$ fragment (the size of scFv containing Th epitope) is convincingly demonstrable by RT-PCR only in the immunized spleen. Naturally, Id-Th does not exist as such in B-cells; no mRNA corresponding to Id-Th has been detected in normal tissues or $2 \mathrm{C} 3$ tumor except when the plasmid DNA incorporates as the transgene in vivo. Further corroboration also comes from the demonstration of a $786 \mathrm{bp}$ fragment in transfected mastocytoma P815 (see Figs. 2a and 2b).
Here $\mathrm{scFv}$ is derived from a hybrid lymphoma, 2C3, which as previously reported secretes a hapten-specific antibody with no mutation in the variable regions [8]. However, immunoglobulins are nominal antigens, and exhibit weak immunogenicity in syngeneic systems; this is the rationale for constructing scFv encoding VH-VL and a Th epitope. Many investigators have reported similar modifications. For instance, a tetanus toxin fragment $\mathrm{C}$ derived non-self Th epitope has been shown to improve immunogenicity of DNA plasmid vaccine [13]. In this study, we used a Th epitope as a linker in constructing the $\mathrm{scFv}$ plasmid. This epitope selected from tetanus toxin tt830-844 is associated with its carboxyl terminal in the translocation domain of toxin heavy chain [14], and has been reported to be a universal $\mathrm{T}$ helper epitope $[9,15]$. The usefulness of this universal Th epitope has been reported in the treatment or prevention of lymphoma [15b]. In one study reported by Tymciu et al. [9b], quite an enhanced humoral immune response was observed with a specific construct of $\mathrm{scFv}$ containing a very similar $\mathrm{Th}$ epitope. We also show here that significant reduction occurs in serum TAA level with just a single injection of the Id-Th construct. Evidently, intrasplenic administration of the vaccine evokes neutralizing antibodies to delay the appearance of the TAA level in the immunized animal. Immunization with the construct containing only the Th epitope reduces this tumor antigen level by $52.4 \%$ (see Fig. 3). Since our previous study has shown the inadequacy of a plain $\mathrm{scFv}$ plasmid in this regard [8], inclusion of a Th epitope seems warranted. Although this inclusion of the Th in the construct significantly lowers serum $2 \mathrm{C} 3 \mathrm{Ig}$ level (nominal TAA) in tumor-challenged $\mathrm{BALB} / \mathrm{c}$ mice, it does not improve survival rates. Since the idiotype is only a differentiation antigen with no housekeeping function, its down regulation may not significantly affect tumor growth. 
We have also studied the effect of an additional, widely used $\mathrm{CpG}$ adjuvant to improve idiotype immunogenicity. It is apparent that $\mathrm{CpG} 1826$ adjuvants enhance immunogenicity of $\mathrm{scFv}$ plasmids. Inclusion of both Th epitope and $\mathrm{CpG}$ in Id-Th vaccine decreases TAA level by $64.9 \%$, and prolongs survival of mice following tumor challenge. Our preliminary data indicates Id-Th vaccine without $\mathrm{CpG}$ increases arginase activity of splenic macrophage implying the alternative macrophage activation pathway M2 [16]. The inclusion of CpG ODN 1826 with the Id-Th, in contrast, favors the M1 or classical pathway of macrophage involving nitric oxide synthase [16]. This implies a switch to Th1 pathway [17] improving prophylactic efficacy of the vaccine formulation both in terms of decreased serum TAA level and the survival rates. How $\mathrm{CpG}$ increases the effectiveness and immunogenicity of scFv plasmid of $2 \mathrm{C} 3$ tumor, however, remains to be addressed.

\section{ACKNOWLEDGMENTS}

We appreciate the statistics assistance of Drs George Bakken and Adam Hoffman, and graphic design of Steve Baker. Many thanks are also due to Mrs. Deborah Flurkey for proofreading this manuscript. This work was supported by NIH Fed 097, Eagles' Art Ehrmann Cancer grant, Indiana Academy of Science, ISU Graduate School, Office of the Sponsored Program and Department of Biology.

\section{REFERENCES}

[1] Lemieux, P. Technological advances to increase immunogenicity of DNA vaccines. [Review]. Expert Rev. Vaccines, 2002, 1(1), 8593.

[2] Goldsby, R. A.; Kindt, T. J.; Osborne, B. A.; Kuby, J. Cells and organs of the immune system. In: Kuby Immunology, $4^{\text {th }}$ ed.; W.H. Freeman: New York, 2000; pp. 51-53.

[3] (a) Kundig, T. M.; Bachmann, M. F.; DiPaolo, C.; Simard, J. J.; Battegay, M.; Lother, H.; Gessner, A.; Kuhlcke, K.; Ohashi, P. S.; Hengartner, H.; Zinkernagel, R. M. Fibroblasts as efficient antigenpresenting cells in lymphoid organs. Science, 1995, 268(5215), 1343-1347; (b) Velikovsky, C. A.; Cassataro, J.; Sanchez, M.; Fossati, C. A.; Fainboim, L.; Spitz, M. Single-shot plasmid DNA intrasplenic immunization for the production of monoclonal antibodies. Persistent expression of DNA. J. Immunol. Methods, 2000, 244(1-2), 1-7; (c) Maloy, K. J.; Erdmann, I.; Basch, V.; Sierro, S.; Kramps, T. A.; Zinkernagel, R. M.; Oehen, S.; Kundig, T. M. Intralymphatic immunization enhances DNA vaccination. Proc. Natl. Acad. Sci. USA, 2001, 98(6), 3299-3303; (d) White, S. A.; LoBuglio, A. F.; Arani, R. B.; Pike, M. J.; Moore, S. E.; Barlow, D. L.; Conry, R. M. Induction of anti-tumor immunity by intrasplenic administration of a carcinoembryonic antigen DNA vaccine. J. Gene Med., 2000, 2(2), 135-140; (e) Gerloni, M.; Billetta, R.; Xiong, S.; Zanetti, M. Somatic transgene immunization with DNA encoding an immunoglobulin heavy chain. DNA Cell Biol., 1997, 16(5), 611-625; (f) Cano, A.; Fragoso, G.; Gevorkian, G.; Terrazas, L. I.; Petrossian, P.; Govezensky, T.; Sciutto, E.; Manoutcharian, K. Intraspleen DNA inoculation elicits protective cellular immune responses. DNA Cell Biol., 2001, 20(4), 215-221; (g) Cayeux, S.; Bukarica, B.; Buschow, C.; Charo, J.; Bunse, M.; Dorken, B.; Blankenstein, T. In vivo splenic $\mathrm{CD} 11 \mathrm{c}$ cells downregulate CD4 T-cell response thereby decreasing systemic immunity to gene-modified tumour cell vaccine. Gene Ther., 2007, 14(20), 1481-1491; (h) Munoz-Montesino, C.; Andrews, E.; Rivers, R.; Gonzalez-Smith, A.; Moraga-Cid, G.; Folch, H.; Cespedes, S.; Onate, A. A. Intraspleen delivery of a DNA vaccine coding for superoxide dismutase (SOD) of Brucella abortus induces SOD-specific CD4+ and CD8+ T cells. Infect. Immun., 2004, 72(4), 2081-2087.

[4] (a) Klinman, D. M. Immunotherapeutic uses of CpG oligodeoxynucleotides. [Review]. Nat. Rev., 2004, April, 1-10; (b) Krieg, A.
M. CpG motifs: the active ingredient in bacterial extracts? [Review]. Nat. Med., 2003, 9(7), 831-5.

[5] Kwissa, M.; Amara, R. R.; Robinson, H. L.; Moss, B.; Alkan, S.; Jabbar, A.; Villinger, F.; Pulendran, B. Adjuvanting a DNA vaccine with a TLR9 ligand plus Flt3 ligand results in enhanced cellular immunity against the simian immunodeficiency virus. $J$. Expert Med., 2007, 204(11), 2733-2746.

[6] Grossmann, C.; Tenbusch, M.; Nchinda, G.; Temchura, V.; Nabi, G.; Stone, G.; Kornbluth, R.; Uberla, K. Enhancement of the priming efficacy of DNA vaccines encoding dendritic cell-targeted antigens by synergistic toll-like receptor ligands. BMC Immunol., 2009, $10(1), 43$.

[7] (a) Lonsdorf, A. S.; Kuekrek, H.; Stern, B. V.; Boehm, B. O.; Lehmann, P. V.; Tary-Lehmann, M. Intratumor CpG-oligodeoxynucleotide injection induces protective antitumor $\mathrm{T}$ cell immunity. J. Immunol., 2003, 171(8), 3941-3946; (b) Davila, E.; Celis, E. Repeated administration of cytosine-phosphorothiolated guanine-containing oligonucleotides together with peptide/protein immunization results in enhanced CTL responses with anti-tumor activity. J. Immunol., 2000, 165(1), 539-547; (c) Hartmann, G.; Weeratna, R. D.; Ballas, Z. K.; Payette, P.; Blackwell, S.; Suparto, I.; Rasmussen, W. L.; Waldschmidt, M.; Sajuthi, D.; Purcell, R. H.; Davis, H. L.; Krieg, A. M. Delineation of a CpG phosphorothioate oligodeoxynucleotide for activating primate immune responses in vitro and in vivo. J. Immunol., 2000, 164(3), 1617-1624; (d) Jakob, T.; Walker, P. S.; Krieg, A. M.; Udey, M. C.; Vogel, J. C. Activation of cutaneous dendritic cells by CpG-containing oligodeoxynucleotides: a role for dendritic cells in the augmentation of Th1 responses by immunostimulatory DNA. J. Immunol., 1998, 161(6), 3042-3049; (e) Oumouna, M.; Mapletoft, J. W.; Karvonen, B. C.; Babiuk, L. A.; van Drunen Littel-van den Hurk, $\mathrm{S}$. Formulation with $\mathrm{CpG}$ oligodeoxynucleotides prevents induction of pulmonary immunopathology following priming with formalininactivated or commercial killed bovine respiratory syncytial virus vaccine. J. Virol., 2005, 79(4), 2024-2032; (f) Chu, R. S.; Askew, D.; Harding, C. V. CpG DNA switches on Th1 immunity and modulates antigen-presenting cell function. [Review]. Curr. Top. Microbiol. Immunol., 2000, 247, 199-210.

[8] Laxmanan, S.; Stuart, G. W.; Ghosh, S. K. A stable single-chain variable fragment expressing transfectoma demonstrates induction of idiotype-specific cytotoxic T-cells during early growth stages of a murine B-lymphoma. Cancer Immunol. Immunother., 2001, 50(8), 437-444.

[9] (a) Boeckler, C.; Dautel, D.; Schelte, P.; Frisch, B.; Wachsmann, D.; Klein, J. P.; Schuber, F. Design of highly immunogenic liposomal constructs combining structurally independent B cell and T helper cell peptide epitopes. Eur. J. Immunol., 1999, 29(7), 2297 2308; (b) Tymciu, S.; Durieux-Alexandrenne, C.; Wijkhuisen, A.; Creminon, C.; Frobert, Y.; Grassi, J.; Couraud, J. Y.; Boquet, D. Enhancement of antibody responses in DNA vaccination using a vector encoding a universal T-helper cell epitope. DNA Cell Biol., 2004, 23(6), 395-402.

[10] Lim, S. Y.; Laxmanan, S.; Stuart, G.; Ghosh, S. K. Anti-lymphoma immunity: relative efficacy of peptide and recombinant DNA vaccine. Cancer Detect. Prev., 2001, 25(5), 470-478.

[11] Krieg, A. M.; Yi, A. K.; Matson, S.; Waldschmidt, T. J.; Bishop, G. A.; Teasdale, R.; Koretzky, G. A.; Klinman, D. M. CpG motifs in bacterial DNA trigger direct B-cell activation. Nature, 1995, 374(6522), 546-549.

[12] Aurora, D. Determination of the optimal form of a DNA vaccine to induce an effective immune response against a murine B-Cell lymphoma. Thesis, Indiana State University, 2003.

[13] (a) Spellerberg, M. B.; Zhu, D.; Thompsett, A.; King, C. A.; Hamblin, T. J.; Stevenson, F. K. DNA vaccines against lymphoma: promotion of anti-idiotypic antibody responses induced by single chain Fv genes by fusion to tetanus toxin fragment C. J. Immunol., 1997, 159(4), 1885-1892; (b) King, C. A.; Spellerberg, M. B.; Zhu, D.; Rice, J.; Sahota, S. S.; Thompsett, A. R.; Hamblin, T. J.; Radl, J.; Stevenson, F. K. DNA vaccines with single-chain Fv fused to fragment $\mathrm{C}$ of tetanus toxin induce protective immunity against lymphoma and myeloma. Nat. Med., 1998, 4(11), 1281-1286; (c) Rice, J.; Elliott, T.; Buchan, S.; Stevenson, F. K. DNA fusion vaccine designed to induce cytotoxic $\mathrm{T}$ cell responses against defined peptide motifs: implications for cancer vaccines. $J$. Immunol., 2001, 167(3), 1558-1565. 
[14] Halpern, J. L.; Neale, E. A. Clostridial Neurotoxins: the Molecular Pathogenesis of Tetanus and Botulism. In: Neurospecfic Binding, Internalization, and Retrograde Axonal Transport., Montecucco, C., Ed. Springer New York, 1995; pp. 221-241.

[15] (a) Corradin, G.; Watts, C. Clostridial neurotoxins : the molecular pathogenesis of tetanus and botulism. In: Cellular Immunology of Tetanus Toxoid., Montecucco, C., Ed. Springer: New York, 1995; pp. 77-87; (b) Yu, Z.; Healy, F.; Valmori, D.; Escobar, P.; Corradin, G.; Mach, J. P. Peptide-antibody conjugates for tumour therapy: a MHC-class-II-restricted tetanus toxin peptide coupled to an anti-Ig light chain antibody can induce cytotoxic lysis of a human B-cell lymphoma by specific CD4 T cells. Int. J. Cancer, 1994, 56(2), 244-248; (c) Kumar, A.; Arora, R.; Kaur, P.; Chauhan, V. S.; Sharma, P. "Universal" T helper cell determinants enhance immunogenicity of a Plasmodium falciparum merozoite surface antigen peptide. J. Immunol., 1992, 148(5), 1499-1505.

[16] Goerdt, S.; Orfanos, C. E. Other functions, other genes: alternative activation of antigen-presenting cells. [Review]. Immunity, 1999, 10(2), 137-142.

[17] Mills, C. D.; Kincaid, K.; Alt, J. M.; Heilman, M. J.; Hill, A. M. M-1/M-2 macrophages and the Th1/Th2 paradigm. J. Immunol., 2000, 164(12), 6166-6173.

(C) Li and Ghosh; Licensee Bentham Open.

This is an open access article licensed under the terms of the Creative Commons Attribution Non-Commercial License (http://creativecommons.org/licenses/by$\mathrm{nc} / 3.0 /$ ) which permits unrestricted, non-commercial use, distribution and reproduction in any medium, provided the work is properly cited. 